\title{
Analysis of Junior High School Students' Motivation in Attending the Learning of PE in Bali and East Java
}

\author{
$1^{\text {st }}$ Lokananta Teguh H. W \\ Physical Education, Health and \\ Recreation \\ State University of Malang \\ Malang, Indonesia \\ Lokananta.teguh.fik@um.ac.id \\ $4^{\text {th }}$ Made Agus Wijaya, \\ Physical Education, Health and \\ recreation \\ Ghanesa University of Education \\ Bali, Indonesia \\ wijaya.madeagus@undiksha.ac.id
}

\author{
$2^{\text {nd }}$ Febrita Paulina Heynoek* \\ Physical Education, Health and \\ Recreation \\ State University of Malang \\ Malang, Indonesia \\ febrita.paulina.fik@um.ac.id
}

\author{
$3^{\text {rd }}$ Ari Wibowo Kurniawan \\ Physical Education, Health and \\ Recreation \\ State University of Malang \\ Malang, Indonesia \\ ari.wibowo.fik@um.ac.id
}

\begin{abstract}
The objective to be achieved in this research is to describe students' motivation in attending PE education in Bali and East Java. The data analysis method uses quantitative analysis and is processed into descriptive statistics, namely percentage and mean analysis. Intrinsic Motivation results get a percentage for Singaraja $23.3 \%$, and Malang was $24.9 \%$. Identified Regulation Singaraja was $\mathbf{2 3 . 4 \%}$, for Malang was 24.1\%. The Introjected Regulation of Singaraja was $19.6 \%$, and Malang City is $19.1 \%$. External Regulation of Singaraja is $20.1 \%$, for Malang was $19.2 \%$. Amotivation of Singaraja is $13.6 \%$, for Malang was $12.7 \%$. The conclusion was that students' motivation in Malang, East Java, was higher in Intrinsic Motivation and Identified Regulation indicators.
\end{abstract}

Keywords—physical education, motivation.

\section{INTRODUCTION}

Physical education, Sports, and Health (PE) is one of the intracurricular lessons taught in schools, both primary and secondary levels [1]. In addition to the general goal of achieving overall educational goals, PE aims explicitly to stimulate all student growth and development [2].

$\mathrm{PE}$ has an essential role in the students' life development. In his book "Foundations of Physical Education," physical education goals have several categories [3]. These categories include, a) for physical development, which relates to activities that involve physical strength; b) the development of motion, which includes the ability to perform movements effectively, efficiently, smoothly, and beautifully; c) mental development, which leads to the ability to think and interpret the whole knowledge of physical education into its environment; and d) social development related to the ability of students to adapt to a group or society. Based on research conducted by Sdrolias, a quality PE program will help improve health-related fitness and psychological well-being in middle school students [4].

It is necessary to have student learning motivation in participating in learning to achieve PE's learning objectives.
However, the fact is that there have been many problems related to these students' motivation until now. One of them is that adolescent students are not motivated to do physical activity in learning at school and outside of school [5]. If students are encouraged through themselves, it will support their role and involvement in the learning process [6]. It was further explained that these students would view that PE learning was significant for their educational process.

Motivation is the driving force for human behavior as well as a determinant of behavior. Motivation can also be action regarding behavior, including the setting, goals, and direction of a person's behavior. Motivation is a driving force that can generate activity in living things, cause behavior, and direct them towards certain goals. Meanwhile, according to Hoy and Miskel, motivation is complex forces, drives, needs, statements, tensions, or other mechanisms that initiate and maintain desired activities towards achieving personal goals. 7].

Learning $\mathrm{PE}$ in each region has different characteristics because there are differences in culture, religion, climate, and geographical areas. For this reason, researchers conducted in two different regions, namely East Java and Bali. These two regions have different individual characteristics. Bali is a region with a varied population density due to being a tourism area, which often mingles with foreign and domestic tourists. Meanwhile, in East Java as a tourism area too, tourists are dominated by domestic tourists.

Based on the importance of physical education for female students, especially female students, and seeing that no research leads to learning motivation in $\mathrm{PE}$, it is necessary to analyze female students' motivation in participating in PE learning in Bali and East Java.

\section{METHOD}

This study used a quantitative descriptive research design by describing student motivation in participating in $\mathrm{PE}$ 
learning and the population in this study. In this study, the research subjects were junior high school students, class VII, VIII, and IX in Bali, Singaraja. Meanwhile, in East Java, Malang, sample selection used random cluster sampling - the number of samples in each region 540 students in Bali and 540 students in East Java.

The instrument used in this study was a non-test that a motivation questionnaire in physical education learning. The questionnaire was given through a questionnaire sheet and distributed to each student. A questionnaire was a data collection method whose instrument used a questionnaire containing written statements/questions. The aim was to obtain information from the respondent regarding what he or she experienced.

The data was collected using a learning motivation questionnaire about PE. The questionnaire was given online by using google form. This motivation questionnaire was developed by [8]. The questionnaire consisted of 4 categories of motivation: Amotivation, External Regulation, Identified Regulation, and Intrinsic Motivation. The questionnaire consisted of 20 questions or answers choices. The scale used was a Likert scale 1-7 by looking at the suitability or agreement from 1 to 7 .

\section{RESULT}

This questionnaire was distributed to schools in East Java to get 540 respondents and Bali to get 540 respondents. The respondents were 1,080 students who participated in Physical Education for Sports and Health.

\section{A. Distribution of Research Data}

Before data analysis and concluding the proposed hypothesis, the distribution of samples and descriptions of the initial data would be presented. The following was the distribution of the research samples used.

Table 1 Distribution of Research Samples

\begin{tabular}{lrr}
\hline Region & $\mathbf{f}$ & $\mathbf{P ( \% )}$ \\
\hline East Java, Malang & 540 & $50 \%$ \\
Bali, Singaraja & 540 & $50 \%$ \\
\hline \multicolumn{1}{c}{$\mathbf{N}$} & $100 \%$ \\
\hline Catatan: & \\
$\mathrm{f} \quad$ = Number of respondents who answered & \\
$\mathrm{N} \quad=$ Total number of respondents & \\
$\mathrm{P}(\%)=$ Percentage &
\end{tabular}

\section{B. Description Analysis}

In this analysis, there was a description of motivation from Singaraja, Bali, and a description of students' motivation from Malang City, East Java. The results of the descriptions that have been calculated from SPSS were described as follows:

Table 2 Description of Students' Motivation in Singaraja, Bali

\begin{tabular}{lccccc}
\hline & $\begin{array}{l}\text { Intrinsic } \\
\text { Motivation }\end{array}$ & $\begin{array}{l}\text { Identified } \\
\text { Regulation }\end{array}$ & $\begin{array}{c}\text { Introjected } \\
\text { Regulation }\end{array}$ & $\begin{array}{l}\text { External } \\
\text { Regulation }\end{array}$ & Amotivation \\
\hline $\mathrm{N} \quad$ Valid & 540 & 540 & 540 & 540 & 540 \\
$\quad$ Missing & 0 & 0 & 0 & 0 & 0 \\
Mean & 20.82 & 20.98 & 17.54 & 18.04 & 12.12 \\
Median & 20.00 & 20.00 & 18.00 & 18.00 & 12.00 \\
Mode & 20 & 20 & 20 & 20 & 10 \\
Std.Deviation & 3.322 & 3.261 & 4.827 & 4.138 & 4.456
\end{tabular}

\begin{tabular}{lccccc}
\hline & $\begin{array}{l}\text { Intrinsic } \\
\text { Motivation }\end{array}$ & $\begin{array}{l}\text { Identified } \\
\text { Regulation }\end{array}$ & $\begin{array}{l}\text { Introjected } \\
\text { Regulation }\end{array}$ & $\begin{array}{l}\text { External } \\
\text { Regulation }\end{array}$ & Amotivation \\
\hline Variance & 11.037 & 10.634 & 23.303 & 17.121 & 19.860 \\
Range & 18 & 22 & 24 & 24 & 24 \\
Minimum & 10 & 6 & 4 & 4 & 4 \\
Maximum & 28 & 28 & 28 & 28 & 28 \\
Sum & 11244 & 11330 & 9470 & 9739 & 6544 \\
\hline
\end{tabular}

\section{Intrinsic Motivation of Students in Singaraja, Bali}

Intrinsic Motivation was obtained by using four questions to 540 respondents. Based on table 4, it was known that the mean number of Intrinsic Motivation was 20.82. For the mean value of the Intrinsic Motivation, the indicator was 20.00. From the data mode, most of the values that often appear are 20. The standard deviation of the Intrinsic Motivation indicator was 3.322 indicating the variations contained in thwas indicator. The variance shown in Intrinsic Motivation was 11.037 . The range of values was 18 . For the minimum value, get a value of 10 and a maximum value of 28 . And for Sum, all respondents' answers add up. All get a value of 11,244 .

\section{Identified Regulation of Students in Singaraja, Bali}

Identified Regulation was obtained by using four questions to 540 student respondents in Singaraja Regency, Bali. Based on table 4, it was known that the Mean number of Identified Regulations was 20.98. The median value of the Identified Regulation indicator was 20.00. From the mode data, most of the values that often appear are 20. The standard deviation of the Identified Regulation indicator was 3.261, indicating the variations contained in was indicator. The variance shown in the Identified Regulation was 10.634. The range of values was 22. For the minimum value, get a value of 6 and a maximum value of 28. And for Sum, all respondents' answers add up. All get a value of 11,330 .

\section{Introjected Regulation of Students in Singaraja, Bali}

Introjected Regulations were obtained using four questions to 540 student respondents in Singaraja Regency, Bali. Based on table 4, it was known that the mean number of Introjected Regulation was 17.54. The median value of the Introjected Regulation indicator was 18.00. From the mode data, most of the numbers that often appear are 20. The standard deviation of the Introjected Regulation indicator of 4,827 shows the variations contained in thwas indicator. The variance shown in the Introjected Regulation was 23,303. The range of values was 24 . The minimum value was 4 , and the maximum value was 28. And for Sum, all respondents' answers add up. All get a value of 9,470 .

\section{External Regulation of Studnets Singaraja, Bali}

External Regulation was obtained by using four questions to 540 student respondents in Singaraja Regency, Bali. Based on table 4, it was known that the mean number of External Regulations was 18.04. The median value of the External Regulation indicator was 18.00 . From the mode data, most of the numbers that often appear are 20. The standard deviation of the External Regulation indicator was 4.138, indicating the 
variations contained in was indicator. The variance shown in the External Regulation was 17,121 . The range of values was 24 . For the minimum value, get a value of 4 and a maximum value of 28. And for Sum, all respondents' answers add up. All get a value of 9,739 .

\section{Amotivation of Students Singaraja, Bali}

Amotivation was obtained by using four questions to 540 student respondents in Singaraja Regency, Bali. Based on table 4, it was known that the mean number of amotivations was 12.12. The median value of the Amotivation indicator was 12.00. From the data mode, most of the numbers that often appear are 10. The standard deviation of the Amotivation indicator was 4.456 indicating the variations contained in thwas indicator. The variance shown in Amotivation was 19,860 . The range of values was 24 . For the minimum value, get a value of 4 and a maximum value of 28 . And for Sum, all respondents' answers add up. All get a value of 6,544.

Table 3 Descriptions of Student Motivation in Malang, East Java

\begin{tabular}{|c|c|c|c|c|c|}
\hline & $\begin{array}{l}\text { Intrinsic } \\
\text { Motivation }\end{array}$ & $\begin{array}{l}\text { Identified I } \\
\text { Regulation I }\end{array}$ & $\begin{array}{l}\text { Introjected } \\
\text { Regulation }\end{array}$ & $\begin{array}{l}\text { External } \\
\text { Regulation } A\end{array}$ & otivation \\
\hline $\mathrm{N}$ Valid & 540 & 540 & 540 & 540 & 540 \\
\hline Missing & 0 & 0 & 0 & 0 & 0 \\
\hline Mean & 21.69 & 21.04 & 16.58 & 16.68 & 11.13 \\
\hline Median & 21.00 & 21.00 & 17.00 & 16.00 & 11.00 \\
\hline Mode & 19 & 19 & 16 & 16 & 10 \\
\hline Std. Deviation & 3.713 & 3.790 & 5.091 & 4.691 & 4.103 \\
\hline Variance & 13.789 & 14.36 & 25.918 & 22.00 & 16.832 \\
\hline Range & 24 & 24 & 24 & 24 & 24 \\
\hline Minimum & 4 & 4 & 4 & 4 & 4 \\
\hline Maximum & 28 & 28 & 28 & 28 & 28 \\
\hline Sum & 11711 & 11364 & 8953 & 9009 & 6009 \\
\hline
\end{tabular}

1. Instrinsic Motivation of Studnets Malang, East Java

Intrinsic Motivation was obtained by using four questions to 540 respondents. Based on table 4, it was known that the mean number of intrinsic motivation was 21.69. The mean value of the Intrinsic Motivation indicator was 21.00. From the data mode, most of the values that often appear are 19. The standard deviation of the Intrinsic Motivation indicator was 3,713, indicating the variations contained in thwas indicator. The variance shown in Intrinsic Motivation was 13.789 . The range of values was 24 . The minimum value was four, and the maximum value was 28 . And for Sum, all respondents' answers add up. All get a value of 11,711.

\section{Identified Regulation of Studnets Malang, East Java}

Identified Regulation was obtained by using four questions to 540 student respondents in Singaraja Regency, Bali. Based on table 4, it was known that the Mean number of Identified Regulations was 21.04. The middle value of the Identified Regulation indicator was 21.00. From the mode data, most of the values that often appear are 19. The standard deviation of the Identified Regulation indicator of 3.3790 shows the variations contained in thwas indicator. The variance shown in the Identified Regulation was 14,362. The range of values was 24 . For the minimum value, get a value of
4 and a maximum value of 28. And for Sum, all respondents' answers add up. All get a value of 11,364.

\section{Introjected Regulation of Students Malang, East Java}

Introjected Regulations were obtained using four questions to 540 student respondents in Singaraja Regency, Bali. Based on table 4, it was known that the mean number of Introjected Regulation was 16.58. The median value of the Introjected Regulation indicator was 17.00. From the mode data, most of the numbers that often appear are 16. The standard deviation of the Introjected Regulation indicator was 5.091 , indicating the variation contained in thwas indicator. The variance shown in the Introjected Regulation was 25.918. The range of values was 24 . For the minimum value, get a value of 4 and a maximum value of 28. And for Sum, all respondents' answers add up, and all get a value of 8,953.

\section{External Regulation of Students Malang, East Java}

External Regulation was obtained by using four questions to 540 student respondents in Singaraja Regency, Bali. Based on table 4. it was known that the mean number of External Regulations was 16.68. The median value of the External Regulation indicator was 16.00. From the mode data, most of the numbers that often appear are 16. The standard deviation of the External Regulation indicator was 4.691, indicating the variations contained in thwas indicator. The variance shown in the External Regulation was 22,002. The range of values was 24 . The minimum value was four, and the maximum value was 28. And for Sum, all respondents' answers add up; all get a value of 9.009 .

\section{Amotivation of Students Malang, East Java}

Amotivation was obtained by using four questions to 540 student respondents in Singaraja Regency, Bali. Based on Table 4. it was known that the mean number of amotivations was 11.13. The median value of the Amotivation indicator was 11.00. From the data mode, most of the numbers that often appear are 10. The standard deviation of the Amotivation indicator was 4.103 showing the variations contained in thwas indicator. The variance shown in Amotivation was 16.832 . The range of values was 24 . The minimum value was four, and the maximum value was 28 . And for Sum, all respondents' answers add up, and all get a value of 6.009.

\section{Percentage Analysis}

The data processing performed showed the percentage of the five indicators of Intrinsic Motivation, Identified Regulation, Introjected regulation, External Regulation, Amotivation. The students of Singaraja Regency, Bali, and students from Malang City, East Java are as follows:

\section{Percentage of Motivation in Singaraja, Bali}

Table 4 Percentage of Motivation in Singaraja Bali

\begin{tabular}{lcc}
\hline & Percentage & Frequency \\
\hline Intinsik Motivation & 23,3 & 126
\end{tabular}




\begin{tabular}{lcc} 
& Percentage & Frequency \\
\hline Identified regulation & 23,4 & 127 \\
Introjected regulation & 19,6 & 106 \\
External regulation & 20,1 & 108 \\
Amotivation & 13,6 & 73 \\
Total & $\mathbf{1 0 0 , 0}$ & $\mathbf{5 4 0}$ \\
\hline
\end{tabular}

From the 450 respondents, it can be seen in table 4 of the percentage results and the number of students who are motivated by respondent's consisting of five indicators. It can be seen that Intrinsic Motivation gets a percentage of $23.3 \%$, and the number of respondents who are motivated by the Intrinsic Motivation indicator was 126 respondents. Identified Regulation received a percentage of $23.4 \%$, and the number of respondents motivated by the Identified Regulation indicator was 127 respondents. Introjected Regulation received a percentage of $19.6 \%$, and the number of respondents who were motivated by the Introjected Regulation indicator was 106 respondents. External Regulation received a percentage of $20.1 \%$, and the number of respondents motivated by External Regulation indicators was 108 respondents. Amotivation got $13.6 \%$, and the number of respondents motivated by External Regulation indicators was 73 respondents. The bar chart for Table 4 data can be seen in Figure 1 as follows.

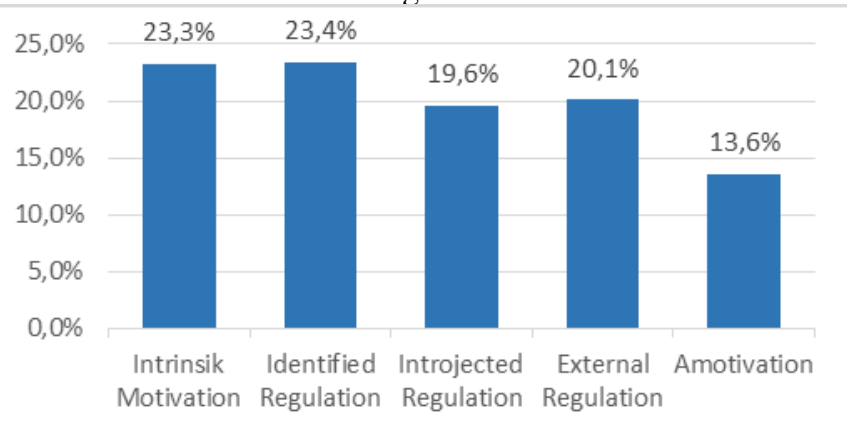

Figure 1. Graphic of Students Motivation Percentage in Singaraja, Bali

\section{Percentage of Motivation in Malang, East Java}

Table 5 Percentage $\mathrm{f}$ Students Motivation in Malang, East Java

\begin{tabular}{lcc}
\hline & Percentage & Frequency \\
\hline Intinsik Motivation & 24,9 & 134 \\
Identified regulation & 24,1 & 130 \\
Introjected regulation & 19,1 & 103 \\
External regulation & 19,2 & 104 \\
Amotivation & 12,7 & 69 \\
Total & $\mathbf{1 0 0 , 0}$ & $\mathbf{5 4 0}$ \\
\hline
\end{tabular}

Of the 450 respondents, it can be seen in table 5 the percentage results and the number of students motivated by respondents consisting of five indicators. It can be seen that Intrinsic Motivation gets a percentage of $24.9 \%$. The number of respondents who are motivated by the Intrinsic Motivation indicator was 134 respondents. Identified Regulation received a percentage of $24.1 \%$, and the number of respondents who were motivated by the Identified Regulation indicator was 130 respondents. Introjected Regulation got a percentage of $19.1 \%$, and the number of respondents motivated by the Introjected Regulation indicator was 103 respondents. External Regulation received $19.2 \%$, and the number of respondents motivated by External Regulation indicators was 104 respondents. Amotivation got a percentage of $12.7 \%$, and the number of respondents who were motivated by External Regulation indicators was 69 respondents. The bar chart for Table 5 data can be seen in Figure 2 as follows.

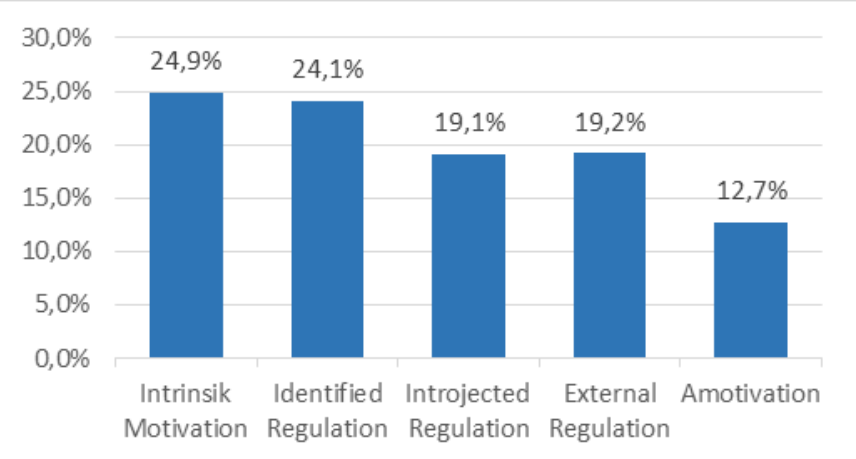

Figure 2. Graphic of Students Motivation Percentage in Malang, East Java

\section{DISCUSSION}

Based on the research results that have been conducted with a sample size of 1,080 students, junior high school students in Singaraja Regency, Bali and Malang City students, East Java, with five different indicators had slightly different from the answers of all respondents.

Intrinsic motivation was contained in a person who will behave for the inherent satisfaction in the behavior itself [9]. The above opinion should be applied by teachers of PE subject everything taught by the teacher as far as possible to attract students intrinsically and avoid sharing material rewards if it was not necessary.

Students who are motivated because the indicator of Identified Regulation was still a lot of the data above proved that students always have a high sense of wanting to know. The factor could be that they want to know directly about this information or if they do so, they will get benefits for themselves. Identified Regulation was considered self-choice, chosen freely, and consistent with individual values and beliefs [9].

The indicator of Introjected Regulation was still higher in Singaraja Regency compared to Malang City. This shows that Bali students from Singaraja Regency have encouragement from themselves in learning sports and health physical education. However, they are required to do it, or there was a feeling of fear if they do not do so. This motivated student was not of his own will, so there was compulsion from his mind, not from others, because there was a sense of obligation [10].

In external Regulation, students from Singaraja Regency tend to be higher than Malang City students because Singaraja students still participate in PE learning. They want to get a gift or reward from the teacher. Usually, students participating in PE learning were very low or lazy to follow. Thus, how the teacher tries to respond to this by giving him praise, grades, prizes, and many more whose purpose of this motivation was so that students are willing to do or take part in learning.

As for the indicator of Amotivation in Singaraja Regency and Malang City, the difference was $0.9 \%$. This percentage was still high in Singaraja Regency, Bali. 
Indirectly, there was a small proportion of students who are not motivated to participate in PE learning. There are 73 students from Singaraja Regency, Bali, and 69 students from Malang City, East Java, who were not motivated to participate in PE learning from the data obtained. Many factors influence unmotivated students, which was because there are many Junior High Schools in Singaraja and Malang City that implemented the Full Day School program. Students who are supposed to learn, they begin at 07.00-13.00 WIB because Full Day School students are studying until 15.15 WIB. According to Heynoek, the motor skills of junior high school students who implement Full Day School are very lacking [11]. The above responses showing junior high school students and students motivation to do PE learning were very low. The Full Day School factor causes it requires them to study continuously. When compared to students doing sports hours in the early morning of lessons and noon at the end of class hours, their motivation for doing sports also varies.

Student motivation must be emphasized even more to students to be motivated within them because motivation has a crucial role in the realm of education and sports. Then, motivation was one factor that can make students concentrate, be more excited, and generate feelings of joy so that they cannot participate in the Sports and Health Physical Education (PE) learning. The main goal was to increase motivation so that students become active students in learning PE, and students care and are aware of the importance of learning PE for their next goals and provisions.

\section{CONCLUSION}

Based on the research results above, it concluded that the motivation of students in Malang, East Java was higher in the indicators of Intrinsic Motivation and Identified Regulation. At the same time, Singaraja, Bali, was low. If for the indicators of Introjected Regulation and External Regulation, the percentage was higher for students in Singaraja, Bali, compared to students in Malang City, East Java. And finally, the indicator of Amotivation was higher in Singaraja, Bali. The difference was $0.9 \%$ from Malang City, East Java.

\section{REFERENCES}

[1] Peraturan Pemerintah Republik Indonesia Nomor 32, "Perubahan Atas Peraturan Pemerintah Nomor 19 Tahun 2005 Tentang Standar Nasional Pendidikan.” 2013.

[2] R. Bailey, Physical Education And Sport In Schools: A Review Of Benefits And Outcomes. 2017.

[3] C. Butcher, Foundations Of Physical Education. London: C.V Mosby Company., 1983.

[4] P. Sdrolias, The Effect Of The Manitoba Grade 11 And 12 High School Physical Education Curriculum On Fitness-Related Health, Academic Achievement And Behavioral Outcomes. Manitoba: Doctoral Dissertation, University Of Manitoba., 2009.

[5] N. Ntoumanis, A. Pensgaard, C. Martin, Dan K. Pipe, “An Idiographic Analysis Of Amotivation In Compulsory School Physical Education.," Journal Of Sport And Exercise Psychology, Vol. 26, No. 2, Hlm. 197214, 2004.

[6] J. A. R. Richard Dan C. L. Bristol, "Student Learning And Motivation In Physical Education, Strategies:," A Journal For Physical And Sport Educators, Vol. 27, No. 2, Hlm. 43-46, 2014.

[7] A. R. Shaleh Dan M. A. Wahab, Psikologi: Suatu Pengantar Dalam Perspektif Islam, 1 Ed. Jakarta: Kencana, 2008.

[8] M. Goudas Dan S. Biddle, "Perceived Motivational Climate And Intrinsic Motivation In School Physical Education Classes," European Journal Of Psychology Of Education, Vol. 9, No. 3, Hlm. 241-250, Sep 1994, Doi: 10.1007/Bf03172783.

[9] C. Sansone Dan J. Harackiewicz, "Intrinsic And Extrinsic Motivation: The Search For Optimal Motivation And Performance," Okt 2012.

[10] H. Kalajas-Tilga, A. Koka, V. Hein, H. Tilga, Dan L. Raudsepp, "Motivational Processes In Physical Education And Objectively Measured Physical Activity Among Adolescents," Journal Of Sport And Health Science, Vol. 00 (2019) 1-10, Jun 2019, Doi: 10.1016/J.Jshs.2019.06.001.

[11] F. P. Heynoek, F. Amiq, Dan G. Rahman, "Survei Tentang Kemampuan Motorik Siswa-Siswi Sekolah Menengah Pertama Full Day Schooldanregulerdi Kota Malang," Skripsi Jurusan Pendidikan Jasmani Dan Kesehatan - Fakultas Ilmu Keolahragaan Um, Vol. 0, No. 0, Okt 2018, Diakses: Mar 02, 2020. [Daring]. Tersedia Pada: Http://KaryaIlmiah.Um.Ac.Id/Index.Php/Penjaskes/Article/View/75402. 